\title{
Genecological Studies in the Azukibean (Phaseolus radiatus L. var. aurea PRAIN), with Special Reference to the Plant Types Used for the Classification of Ecotypes*
}

\author{
Junro TASAKI \\ (Faculty of Education, Niigata University)
}

\section{Introduction}

The Azukibean plant is very sensitive to the environment and its yield decreases greatly when grown under adverse environmental conditions. The clarification of the ecological characteristics of its varieties is, therefore, indispensable for the aquirement of basic data concerning their cultivation and breeding.

The Azukibean, although cultivated since ancient times, has been distributed only in the Orient. Its natural varieties, consigned to perfunctory cultivation, have been scarcely crossed artificially and the number of varieties is limited. Very little exchange of seeds: between different localities have taken place and the natural distribution of each local variety is essentially unaltered. The clarification of the relationship between varietal characteristics and the geographical distribution in the Azukibean is, therefore, rather simple and the ecotypes or regional types are clearly defined. The Azukibean is thus very much suited for investigations that enhance the knowledge of the genecological study in crop science.

In the genecological study of the Azukibean, the investigation of plant type is important because :

1) The plant type is the phenotype showing the fundamental characteristics of the variety.

2) The morphological characteristics of the plant type are closely related to the physiological properties exhibited in the growth and development, the earliness or lateness of the variety, the seed yield, its response to climate, its resistance to insect pests or diseases, etc.

3) The geographical distribution of different plant types provides information about isolated ecotypes, and the phylogenetic process of differentiation into the various ecotypes.

Unfortunately only a little attention has been paid to the investigation of plant types, which actually shows the fundamental nature of the respective varieties. What little investigations that have been conducted along this line have not attempted to elucidate the relationship among plant types and other physiological characteristics, or such observations have been taken perhaps by mere subjective sampling of different types found in cultivated fields or perhaps by seemingly objective but practically invalid numerical indication, that resulted in confused classification and brought no contributions to genecology.

* Presented on 17 th Meeting of Japanese Society of Breeding. April 4; 1960

Received Nov. 10, 1962 
In the present paper, the author has attempted to classify the ecotypes of Azukibean varieties and to determine their genecological significance through the analysis of plant. types.

The author wishes to acknowledge his indebtedness to Dr. Morimasa YAmazaki, Professor of the Tokyo Agricultural University, for his very helpful suggestions, criticisms, and encouragement in regard to this study. The author also wishes to offer his thanks: to Professor Yutaka Fuke, Vice President of Japan Crop Science Society, for his kindness. to peruse the original manuscript.

\section{Literature Review and the Physiology of the Azukibean Plant Type}

As the plant type of the soybean is similar to that of the Azukibean, the author has referred to the studies in soybean plant types by NAGAI (1946), ARIGA (1943), KoBAYASHI (1946), and NAgA'TA (1956). They classified the plant types on the basis of the constitutional elements of plant types, i.e., stem length, branch length, plant width, number of branches, direction of branches, angle between stem and branches, branch curvature, or by measuring the ratio of branch length to stem length or plant width to stem length, etc. Their reports, however, so not clearly describe when the plants had been sown or when the measurements had been taken. (ARIGA measured at the harvest time.) Nevertheless, these methods of classification have contributed much to the clarification of the varieties of soybean. For several years the author has tried to adapt their methods to the Azukibean, but has failed to obtain any definite results. For example, data on the angle between stem and branch, the plant width, and the branch curvature cannot be relied upon because of the effects caused by the unstable weight of branches during the rainy season or by other environmental factors. Moreover in regards to the sowing date, the varieties tend to show no great differences in plant types when sown at a late date. When the measurements are made too late, for example at the harvest time, they are unreliable because of the physical plant damage, etc. In order to distinguish the varietal differences, it is desirable to measure as soon as the plant types become definitely distinctive. Accordingly the author has investigated the other well-grounded elements of plant types, the adequate sowing date, and the time most suitable for measurements.

It has been known for many years that the apical dominance and the lateral inhibition. in the buds of shoots are associated. Thimann and Skoog (1934), VAn Overbeek (1938), Skoog and Tsur (1951), and others have pointed out that a large amount of auxin are: produced by the apical bud and the leaves near the apex and the auxin inhibits directly and indirectly the development of lateral buds. OverbeEk (1935) claims that the dwarf maize contains only a small amount of auxin or has a dull sensitivity to auxin or has some strong function to inactivate auxin. These observations suggest that the external form of the plant types in the Azukibean may be due to its internal physiology, and that the erect and branchy types are determined fundamentally by the quantity and activity of auxin. As a matter of fact, the plant types which can be distinguished at the early seedling stage are the erect and branchy types. 
In this study, the plant types are classified at first into two large groups, the erect and branchy types.

\section{Analysis of the Constitutional Elements in the Plant Types}

\section{A) Materials and Methods}

The experiments were carried out at the field of Educational Faculty, Niigata Univ., Niigata, from 1952 till 1960 to obtain data on the responses to various environments by the Azukibean. In these experiments, there were about 120 varieties which had been gathered by the author from throughout Japan (through prefectural agricultural experiment stations), Manchuria (through the Kungchuling Agricultural Experiment Station), North China (seed samples), Korea (through the Kyung Buk Univ. in Taegu), Okinawa (through the Ryukyu Government, Agricultural Affairs Section), etc. The seeds of all varieties were sown monthly from April till September (in April on the 20 th, in other months on the $15 \mathrm{th}$ ). All plots in fine sandy loam received $3.75 \mathrm{~kg}$ ammonium sulphate, $15.00 \mathrm{~kg}$ superphosphate, and $7.50 \mathrm{~kg}$ potassium chloride per 10 acres. Each plot consisted of double rows $6 \mathrm{~m}$ long with the rows $90 \mathrm{~cm}$ apart. The plants were adequately spaced 20 to $40 \mathrm{~cm}$ apart in the row depending on the variety and the sowing date. Data were taken from 10 plants selected at random and with two replications per plot. In this paper, the data were taken from plants sown on May 15, 1958, and the measurements were made particularly at harvest time in order to observe the developmental changes of the plant types in the growing process, but such measurements should be ordinarily taken in late July. The results of many years have been taken also into consideration.

The constitutional elements selected by the author for the analysis of plant types are as follows :

1) Branchiness The length of the stem from the first to the tenth node is indicated as a. The number of primary branches (branches here refer to those which have two or more nodes) at the peak branching stages (if sown in April or May, the time will be usually in late July) is indicated as b.

$a / b \div 10$ is the index of branchiness. In the present study, the indices ranged from 2.82 to 0.11 . These indices are graded as follows :

\begin{tabular}{c|c|c|c|c|c}
\hline Indices & $\longleftarrow$ & $1.0 \longleftarrow$ & $0.7 \longleftarrow$ & $0.5 \longleftarrow$ & 0.3 \\
\hline $\begin{array}{c}\text { Notation, } \\
\text { Grade }\end{array}$ & $\operatorname{Br} 1$ & $\operatorname{Br} 2$ & $\operatorname{Br} 3$ & $\operatorname{Br} 4$ & $\operatorname{Br} 5$ \\
\hline
\end{tabular}

The erect type with the smallest branchy degree belongs to $\mathrm{Br} 1$, the branchy type with the greatest branchy degree belongs to $\mathrm{Br} 5$.

2) Rigidity or softness (Tapering) The stem which is thick at the base and comparatively thick near the top is erect and rigid. On the other hand, the stem which tapers off and becomes viny near the top is more tender and soft, and more liable to lodging at the internode. The stem of the latter type is similar to the "curved" type in the soybean and indicates a poor activity of the secondary cambium layer in the upper part. The 
extensive branchiness has much to do with the tapering and tenderness.

The diameter of the stem just beneath the attachment of the primary leaves is indicated as a. The diameter of the stem half way between the 10 th and 11 th nodes is indicated as $b . a / b$ is the index of softness. In the present study, the indices of softness ranged from 1.22 to 2.80 . The indices are graded as follows:

\begin{tabular}{c|c|c|c|c|c}
\hline Indices & $\longleftarrow$ & $1.39 \leftarrow$ & $1.59 \leftarrow$ & $1.79 \leftarrow$ & 1.99 \\
\hline $\begin{array}{l}\text { Notation, } \\
\text { Grade }\end{array}$ & $\mathrm{S} 1$ & $\mathrm{~S} 2$ & $\mathrm{~S} 3$ & $\mathrm{~S} 4$ & $\mathrm{~S} 5$ \\
\hline
\end{tabular}

The tenderest with the greatest tapering degree belongs to S5 and the most rigid with the smallest tapering degree belongs to S1.

3) Diameter at the base of stem In addition to the degree of softness explained in 2), it is necessary to know the diameter at the base of the stem, for this indicates to a large extent the length of the growing period (in the other words, the earliness or lateness) of the variety concerned, and the vigor of the plant.

The diameters of the stems are graded as follows:

\begin{tabular}{l|c|c|c|c|c}
\hline Diameters & $\longleftarrow$ & $6.5 \leftarrow$ & $8.0 \leftarrow$ & $9.5 \leftarrow$ & $11.0 \leftarrow$ \\
\hline $\begin{array}{l}\text { Notation, } \\
\text { Grade }\end{array}$ & W1 & W2 & W3 & W4 & W5 \\
\hline
\end{tabular}

4) Length of the longest branch This indicates the final plant height and the vegetative growth or vigor.

The lengths are grades as follows:

\begin{tabular}{l|c|c|c|c|c}
\hline Lengths & $\leftarrow$ & $25 \leftarrow$ & $40 \leftarrow$ & $65 \leftarrow$ & $80 \leftarrow$ \\
\hline $\begin{array}{l}\text { Notation, } \\
\text { Grade }\end{array}$ & L1 & L2 & L3 & L4 & L5 \\
\hline
\end{tabular}

\section{B) Results}

Table 1 presents the actual values of the plant type elements and the grade values of the typical varieties of several regions. From these grade values we can visualize the appearance of the entire plant. This method of numerical treatment of plant types may be simpler and more objective than the qualitative treatment. The typical varieties are mentioned as follows :

Takahashi-Wase, an early variety of Hokkaido, belongs to $\mathrm{Br} 1, \mathrm{~S} 1, \mathrm{~W} 3$, and $\mathrm{L} 1$. This indicates that its branchiness is slight, is an erect type with short branches, and short in height. Its main stem is not so thick at the base, and is not so thin in the upper part which is firm and stiff with little tendency to lodge or become viny.

Oita-Natsu, a summer variety of southwestern Japan, is Br3, S4, W3, L4. It has mod erate branchiness, fairly long branches, a thin stem in the upper part, a little viny and a tendency to lodge.

Manchurian-Red, an early variety of Manchuria, is Br4, S5, W1, L4. It is extensively branched, long, viny, and stretchy branches and a tendency to lodge.

Oita-Nabeyogoshi, an autumn variety of southwestern Japan, is Br5, S5, W5, L5. It 


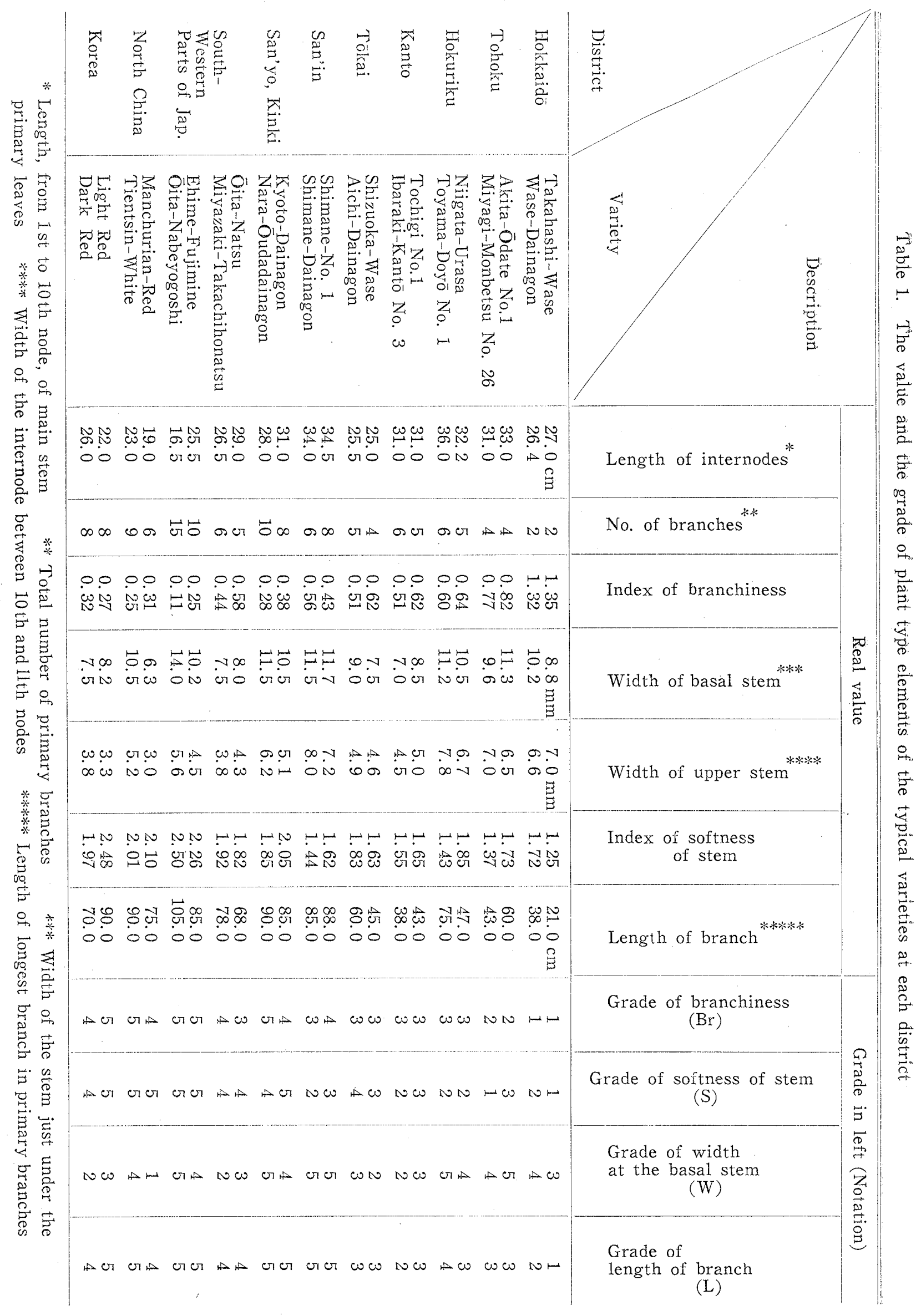


TASAKI : Genecological Studies in the Azukibean (Phaseolus radiatus L. var. aurea PRAIN), with Special Reference to the Plant Types Used for the Classification of Ecotypes

has the greatest branchiness, is the tallest, and the curved stem and branches tend to grow disorderly. It is the latest-ripening variety. It is thick at the base but tapers off at the extremities and has many secondary and tertiary branches, which become very viny. It has a great tendency to extend sidewise and lodge.

In contrast with Fig. 1 or plate 1 5, it seems that this analysis of plant types based on these constitutional elements is simple and satisfactory.

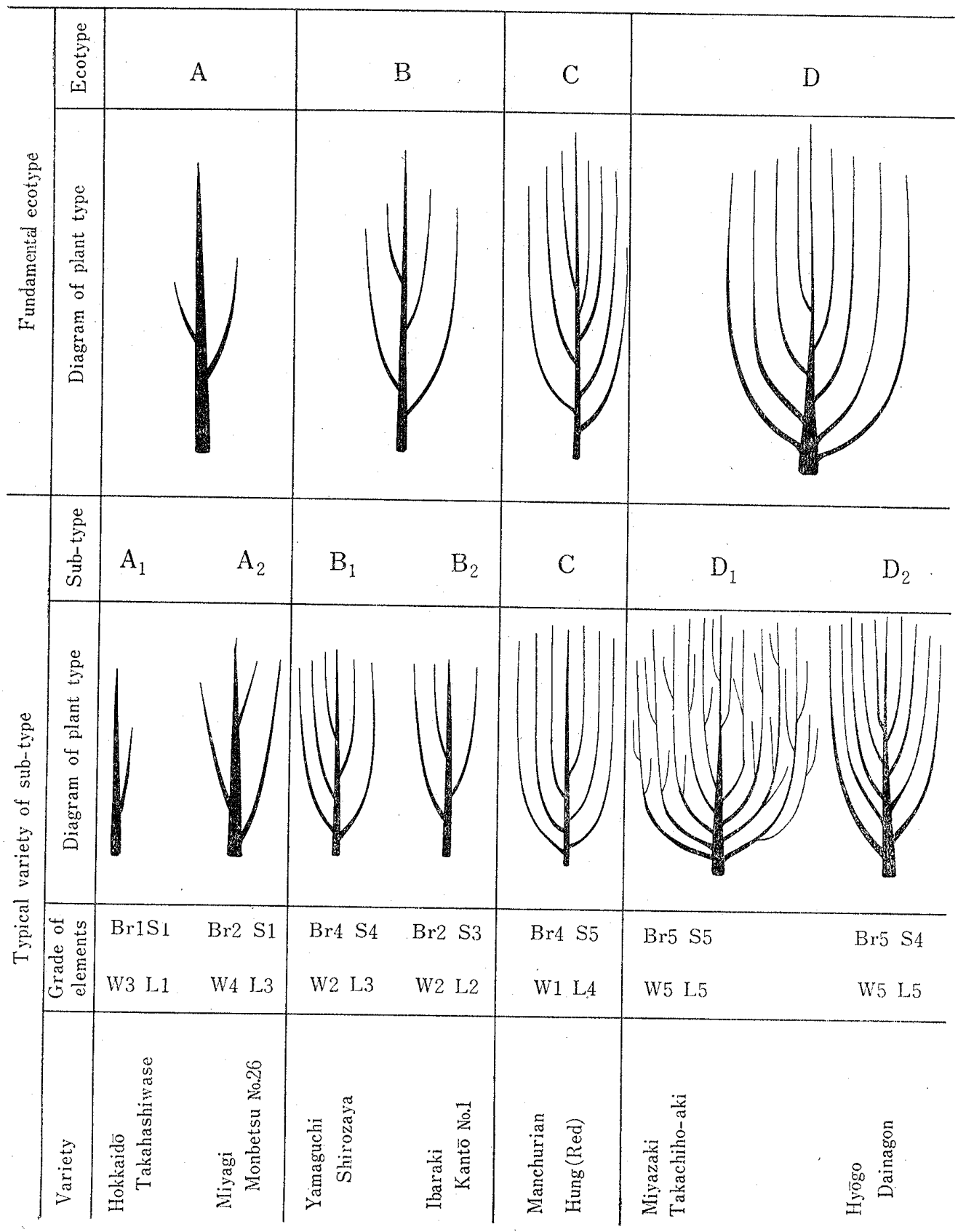

Fig. 1 Diagram of characteristic appearance from the view point of plant type elements in every ecotype 

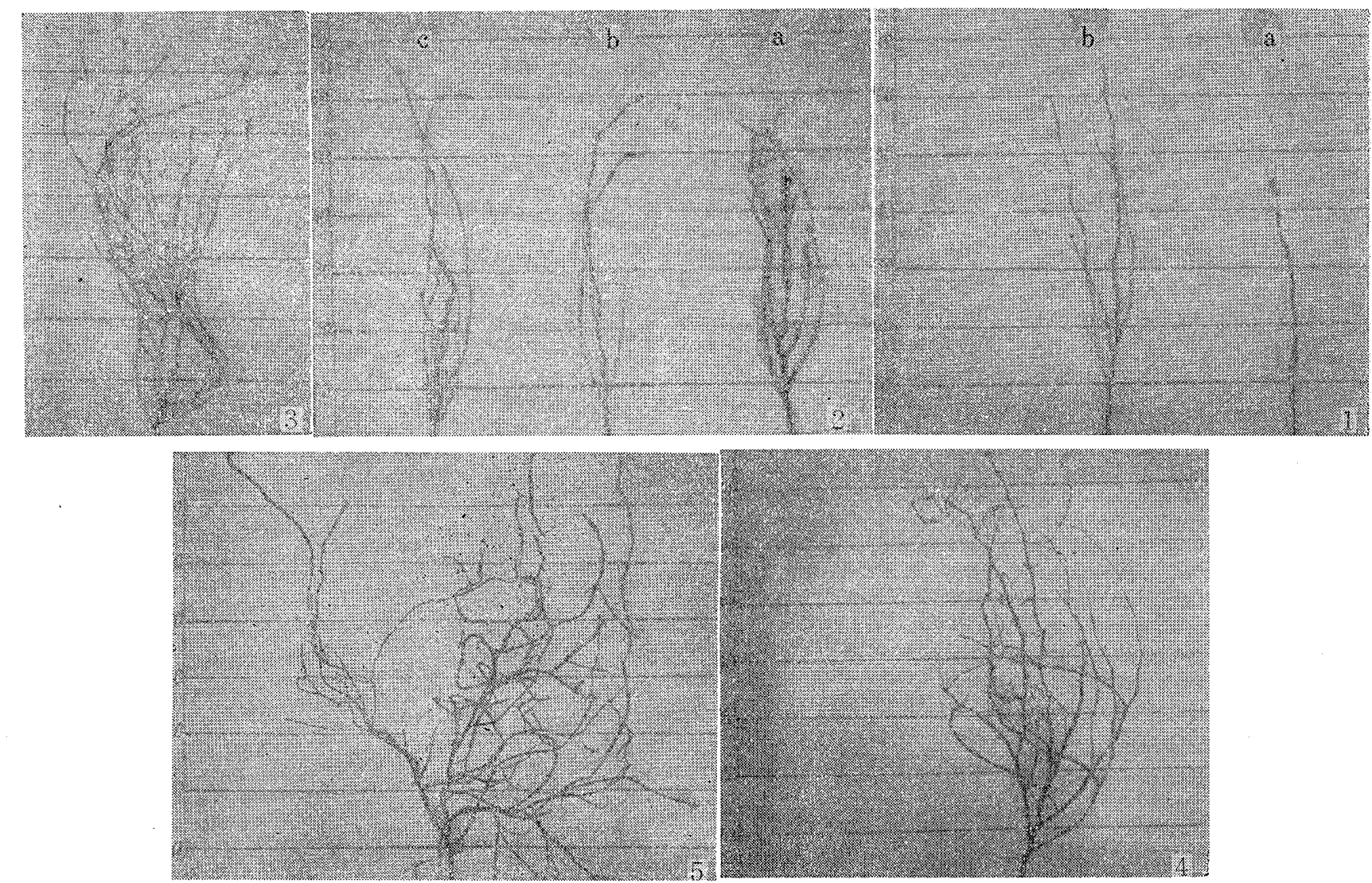

Plates $1 \sim 5$. Plant types of the typical variety in each ecotype 1a: Hokkaidō-Maruba No.1 (A1). 1b: Akita-Ödale No. 2 (A2). 2a: Yamaguchi-Chazaya (B1). 2b: Chiba-Kintoki (B2). 2c: Manchurian Red (C1). 3: Tientsin-Pai (C1). 4 : Okayama-Dainagon (D2). 5 : Köchi-Dainagon (D1).

IV. Grouping of Varieties by Means of the Similarity of Plant Type Elements, and the Classification of the Ecotypes According to the Geographical Distribution of These Groups

The author has attempted to clarify the relationships between the different combinations of each plant type element and the geographical environment of the regions where Azukibean varieties are cultivated; that is, he has attempted to analyze the ecological plant types which have developed through adaptation to the different regional environments with a view to clarify the ecotypes of the Azukibean varieties.

(1) Geographical districution of the varieties vieved from the standpoint of their branchiness

When all the varieties are put into their respective grades of branchiness as shown in. Table 2, the number belonging to each grade is as follows (shown in brackets): $\mathrm{Br} I$ (11), Br2 (17), Br3 (46), Br4 (17), Br5 (32).

So far as the tested varieties are concerned, those with moderate branchiness constitute: the largest proportion, and a fairly large proportion had the greatest branchiness.

Table 2 shows the result after the varieties in each grade are arranged according to 
TASAKI : Genecological Studies in the Azukibean (Phaseolus radiatus L. var. aurea PRAIN), with Special Reference to the Plant Types Used for the Classification of Ecotypes

Table 2. Differences in the geographical distribution of the varieties belonging to each grade of branchiness

\begin{tabular}{|c|c|c|c|c|c|c|}
\hline District & $\mathrm{Br} 1$ & Br 2 & Br 3 & $\mathrm{Br} 4$ & Br 5 & Total \\
\hline Hokkaidō & 8 & 0 & 0 & 0 & 0 & 8 \\
\hline Tōhoku & 2 & 9 & 4 & 1 & 1 & 17 \\
\hline Hokuriku & 1 & 2 & 16 & 2 & 0 & 21 \\
\hline Kanto & 0 & 5 & 14 & 0 & 0 & 19 \\
\hline Tōkai & 0 & 1. & 5 & 0 & 0 & 6 \\
\hline San'in & 0 & 0 & 5 & 1 & 0 & 6 \\
\hline Kinki, San'yo & 0 & 0 & 0 & 2 & 5 & 7 \\
\hline $\begin{array}{l}\text { South-west. part of Jap. } \\
\text { (Summer type) }\end{array}$ & 0 & 0 & 2 & 5 & 0 & 7 \\
\hline " (Autumn type) & 0 & 0 & 0 & 0 & 19 & 19 \\
\hline Manchuria, North China & 0 & 0 & 0 & 4 & 3 & 7 \\
\hline Korea & 0 & 0 & 0 & 2 & 4 & 6 \\
\hline Total & 11 & 17 & 46 & 17 & 32 & 123 \\
\hline
\end{tabular}

their native places. According to this table, the distribution of the varieties, viewed from the standpoint of branchiness, is associated on one hand, with the latitudinal adaptation, and on the other hand, with the existence of regional specialization.

The varieties grown in the continent in the same latitudinal zone, however, show much difference from those in Japan: the varieties in Manchuria, North China, and Korea have stronger branchiness. At any rate, Table 2 shows that different plant types are predominant in different regions.

It is of interest to note that the varieties of grater branchiness are of greater proportion than those of less branchiness, and the former varieties are distributed in the Chinese Continent and the southern parts of Japan. To a large extent, the range of variation in branchiness indicates the route of the distribution of Azukibean and the assumption of the author that the Azukibean culture may have originated in Central or South China. appears reasonable.

\section{(2) Characteristics of regional groups of varieties}

The next procedure attempis to establish the differences of plant type elements other than branchiness. Table 3 shows that plant types differ greatly from region to region. Besides, there is great difference in the products of the values of plant type elements from various regions. The product indicates the size of the plant. The main points in Table 3 are shown in Fig. 2. Fig. 2 reveals that the varieties of the same region have some similarity in their plant type elements and that there exist some common patterns in the respective regions. Based on these common patterns, the Azukibean plant types can be grouped together as follows:

Group 1: The plant has slight branchiness and belongs to the erect type. The stem is firm and stiff, with a thick base. The stem is dominant. The branches are short or long depending on whether the variety is early or late in ripening. Region of Distribution: 
Table 3. The mean values of the plant type elements of the respective districts and the products of these values

\begin{tabular}{|c|c|c|c|c|c|c|}
\hline & $\begin{array}{l}\text { type } \\
\text { ents } \\
\text { itheir } \\
\text { roduct }\end{array}$ & $\mathrm{Br}$ & S & W & $\mathrm{L}$ & Product \\
\hline Hokkaidō & 8 & 1.00 & 1.88 & 3.50 & 1.12 & 7.37 \\
\hline Tohoku & 17 & 2.41 & 2.00 & 4.35 & 3.11 & 65.20 \\
\hline Hokuriku & 21 & 2.90 & 2.57 & 4.42 & 3.14 & 103.43 \\
\hline Kantō & 19 & 2.73 & 2.73 & 2.26 & 2.42 & 40.76 \\
\hline Tōkai & 6 & 2.83 & 3. 66 & 2.16 & 3.00 & 67.11 \\
\hline Sań'in & 6 & 3.16 & 2.33 & 4.66 & 4.50 & 154.39 \\
\hline Kinki, San'yo & 7 & 4.71 & 4.16 & 4.85 & 5.00 & 472.86 \\
\hline $\begin{array}{l}\text { South-west. Jap. } \\
\text { (Summer) }\end{array}$ & 7 & 3.71 & 3.85 & 2.14 & 3.57 & 109.12 \\
\hline$"$ (Autumn) & 19 & 5.00 & 4.84 & 4.52 & 5.00 & 546.92 \\
\hline Machuria, Noth China & 7 & 4.33 & 5.00 & 2.85 & 4.57 & 281.98 \\
\hline Korea & 6 & 4.66 & 4.66 & 3.03 & 4.66 & 306.61 \\
\hline
\end{tabular}

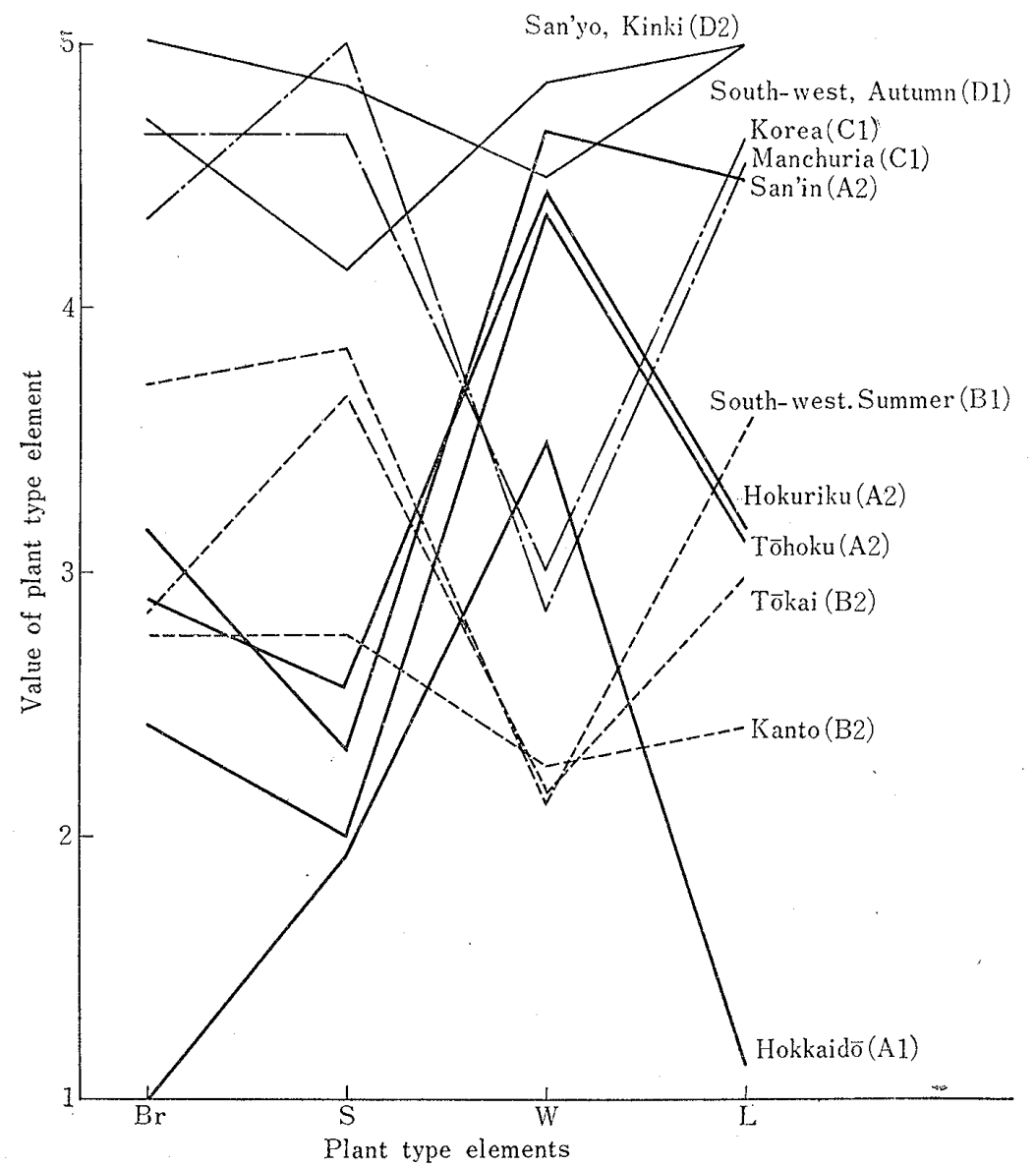

Fig. 2 The mean values of the plant type elements of the varieties in respective districts
Hokkaido, Tohoku, Hokuriku, San'in. (Some are found in the mountainous areas of the northern part of the Kanto District.)

Group 2: The plant has moderate branchiness, the stem is moderately hard, and the tendency to vining is comparatively slight. This is the intermediate type.

Region of Distribution : Chugoku, Shikoku, Kyushu, Okinawa. (summer type in the southwestern parts of Japan), Kanto, Tokai(summer or midseason type on the Pacific Coast of Japan).

Group 3: Plant with a greater branchiness, a soft stem which is not thick at the base, and liable to become viny, stringy, and to lodge.

Region of Distribution : Nor- 
th China, Manchuria, and Korea.

Group 4: The plant shows greatest branchiness, latest ripening, and has a thick basal stem, soft viny extremities, and greatest liability to become viny. It stretches sidewise, and lodges with long entwining branches.

Region of Distribution: Kinki, San'yo, Shikoku, Kyushu. (autumn type in the southwestern parts of Japan.)

So far, the author has described the characteristics of the plant type elements and the products of their values with a view to a practical classification. Though the classification may not yet be perfect, it is a step forward with respect to the Azukibean.

\section{(3) Ecotypes established on the basis of plant type grouping}

As mentioned above, the varieties of similar plant types are distributed in the regions with common ago-climatic conditions and with artificial cropping practice. The varieties, therefore, with respect to the plant types, in a region have adapted themselves to the climatic peculiarities of that region. On this basis, the author has classified the varieties into ecotypes.

Corresponding to plant type groups $1,2,3$, and 4 , ecotypes $\mathrm{A}, \mathrm{B}, \mathrm{C}$, and $\mathrm{D}$ have been established. The ecotypes are divided into sub-types on account of the similarity in plant type elements. The classification of the ecotypes is as follows:

\begin{tabular}{c|c|l|l}
\hline $\begin{array}{c}\text { Basic } \\
\text { ecotype }\end{array}$ & Sub-type & \multicolumn{1}{|c}{ Regions of distribution } & \multicolumn{1}{c}{ Cropping type } \\
\hline \multirow{3}{*}{ A } & A 1 & Hokkaido & Full season cropping \\
& A 2 & Tohoku, Hokuriku, San'in & Full season cropping \\
B & B 1 & Southwestern parts of Japan & Summer cropping \\
& B 2 & Tokai, Kanto & Summer copping or mid-season cropping \\
C & C C 1) & Manchuria, North China, Korea & Full season cropping \\
& D 2) & Central or South China) & (Autumn cropping) \\
D & D 1 & Southwestern parts of Japan & Autumn cropping \\
& D 2 & Kinki, San'yo & Autumn cropping \\
\hline
\end{tabular}

(C 2): Presumable sub-type. Korea: Some of the varieties similar to type A with the dark-green leaf color are found in South Korea.

In the full season type of cropping in all regions, the plant receives much rain during the rainy season in Japan, and is exposed to the longday during the summer solstice, and the shortday and low temperature in autumn. It is possible that some varieties which are included in Type $\mathrm{C}$ are grown in Central or South China. Type $\mathrm{C}$ is designated the type of the Chinese Continent. The Bureau of Agriculture (1919) has reported that the Azukibean is distributed in Anhwei Province, Central China. SAIto (1943) has noted that it is grown in the delta plain of the Yantze. It is possible that the varieties may have adapted themselves to the low latitudinal environment and may belong to Type C 2. The present author regrets that he has not gathered any Azukibean from this area. The classification of all the varieties of Azukibean by plant type elements is presented in Table 4. 
Table 4. Genecological classification of Azukibean varieties based on the ecotypical plant type characteristics

Japan Sea Coast
$\begin{gathered}\text { Jype A } \\ \text { type A)* }\end{gathered}$$\quad \begin{aligned} & \text { Hokkaidö-Takara, -Takahashiwase, -Maruba No. 1, } \\ & \text { - Wasedairy } \bar{u} \text { No. 1, -Kenzaki No. 7, -Chagarawase, } \\ & \text { - Wasemaruba. Iwate-Maruba No. 1. } \\ & \text { Nigata-Wasekurozaya. Miyagi-Takahashiwase. }\end{aligned}$

Type A2- Hokkaido-Wasedainagon. Aomori-Wasedainagon, -Dainagon. Akita-Ödate No. 1.No. 2.No. 3, -Dainagon No. 5. Iwate-Dainagon, -Sapporowasedainagon, -Kiazuki. Miyagi-Dainagon,-Monbetsu No. 26. Yamagata-Daikoku, - Kenzaki. Fukushima-Aka, -Dainakon, -Natsu. Tochigi-Maruba No. 1. Nigata-Koshi, -Uzura, -Kurodane, -Zairaiwase, -Nakatedainagon, -Jōkeidainagon, -Urasa, -Mejiro, -Miomoteshiro, -Miomote No. 1.No. 2. No. 3.No.4, -Zairaidainagon. Nagano-Chūnagon. Toyama-dainagon, -Doyō No. 1. Shimane-Zairai, -...zuki No. 1, -Kenzaki, -Urasa, -Daikoku, -Dainagon.

Japanese
Ecotype

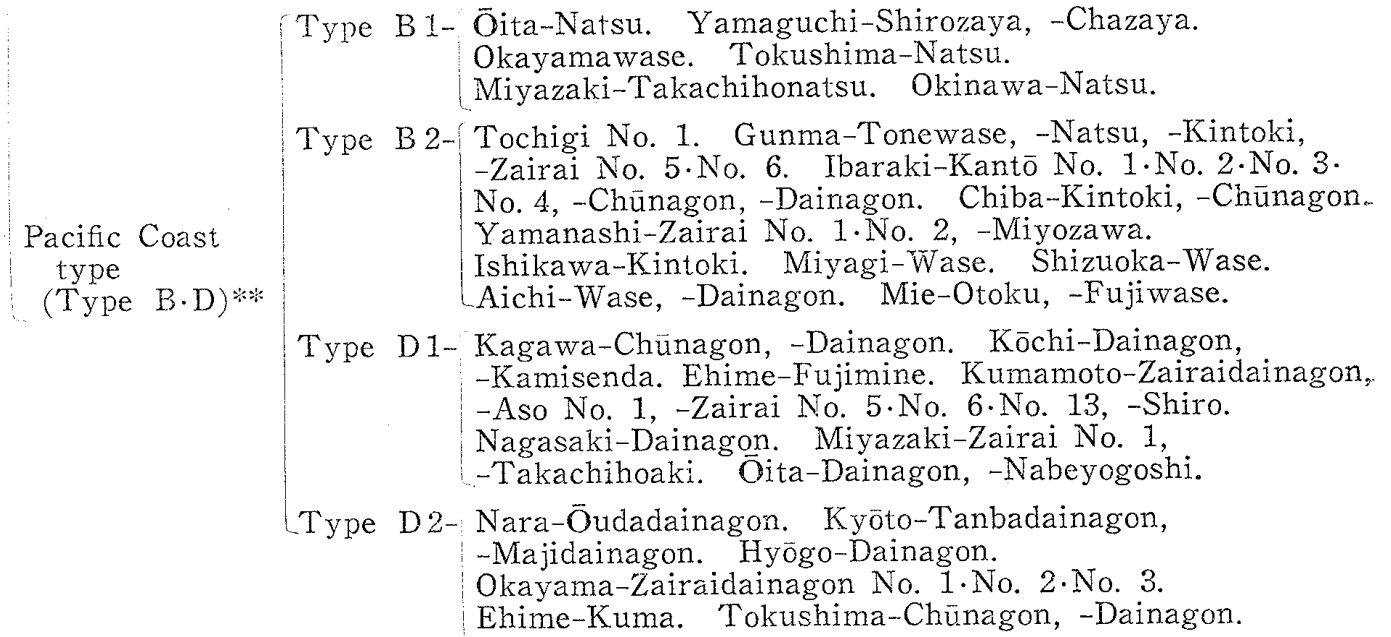

\footnotetext{
Continental Tyanchuria-Hung, -Pai, -Hua, -Li. Tientsin-Pai No. 1 . Ecotype - (TypeC)-Type C1- No. 2,-Hung No.1.No. 2. Korea-Dark Red, -Light Red, -Red Large, -Yellow, -Green, -Dark Red, Jock doo, Kum doo, Huk doo, -Gaegoori Patt, -Baek doo,

* The strain proper to Japan. * * Strains similar to the continental ecotype.
}

\section{Some Considerations with Regard to the Differentiation and Formation of Varieties Based on the Genecological Studies of Plant Types on Azukibean}

The morphological features of the plant types of Azukibeans are very susceptible to the control and selection by environmental factors, and the results of the present study show the process of the varietal differentiation and formation when viewed from the: genecological aspect.

The author believes that the origin of Azukibean may be located in Central or Southern China. This is based on VAvilov's opinion (1926) that was manifested for the: law of geographical regularity in variation and of homologous series in variation, because :

1) The characteristics which probably are dominant and show a great range in variation, may have accumulated geographically into the varieties of the southern region or of the Chinese Continent rather than in those of the northern region or of the Japanese 
Islands. In this case, WeIss's study (1949) of dominant characters in the soybean may be taken with reference to the Azukibean.

2) The characteristics with regard to the plant types are observed in the erect and branchy property, the dwarfish and gigantic character, determinate and indeterminate stems, non-viny and viny branches and early and late varieties, etc.

3) The ecological and physiological characteristics, for example, the various responses to light conditions (the author will be mentioned in the other paper) also show this tendency, with respect to plant types.

4) So far, the author has heard nothing, in spite of his efforts, from Burma, Malaya, Indo-China, and Indonesia about Azukibeans except for Tsuru-Azuli (Phaseolus radiatus: L. var. flexuosus MAтUм.)

The author suggests that the ecotypes of Azukibean may have differentiated and developed as follows: as the result of latitudinal adaptation, the plant became distributed from the origin to the north and its recessive character may have appeared gradually, and the original plant type has become dwarfish. The branchy and the indeterminate characters, however, are maintained throughout the Chinese Continent as the features of Type C. The typical varieties in Japan (Type A) may have lost their original character. In Japan, due to the great influence of the monsoon, the erect and determinate characters: may have become established as the characteristics of Type A. The main factor in the natural selection that leads to the formation of the ecotypes is considered to be the amount of light.

The continental type (Type $\mathrm{C}$ ) is inclined to elongate even under conditions inhibiting. on growth, such as strong light, etc., while the Japanese type (Type A), which has some: attributes of shade plant, grows and develops firmly in the weak light of the rainy season. On the other hand, the summer type in the original home (similar to Type B), may have been selected and differentiated artificially along the direction of early ripening, and may have lost the ability to resist strong light injury and become to ripen early, and have adapted to the weak light condition found in early sowing.

After migrating to Japan, this type became the summer type (Type B1) in the southwestern parts of Japan, when it became distributed farther to the north, it changed into the summer type B2, which is found on the Pacific Coast of Japan. Type C2, which the author presumes to be distributed in Central or Southern China, may be the typical autumn type in these regions. Its plant type elements may be controlled by the dominant factors. This type is believed to flourish vigorously under inhibiting circumstances. After migrating to the north, it seems to have changed to $\mathrm{Cl}$ of the Manchurian ecotype, on the other hand, when it came directly to Japan, it may have turned into D1 in the southwestern districts where it grows normally after late sowing under strong light condition. When sown at a late date, the plants do not usually receive much rain in the rainy season. Migrating farther up the Pacific Coast into San'yo and Kinki Districts, the D1 type may have become Type D2. Type D2 has lost somewhat the characteristic of branchiness and is nearer to the erect type. Type $D$ has the greatest range in variation with regards to the various characteristics. After migrating to San'in, Type D2 may have 
been cultured as a full season crop and grown from the early season. This may have changed it to A2 because of the effects of ecological pressure. This type is also seen in the Hokuriku Districts situated on the Japan Sea Coast and the Tohoku District. Migrating still farther up into Hokkaido, it has turned into Type A1.

In conclusion, the varietal differences are believed to be caused by differences in the environmental factors and have become hereditarily stabilized. Thus each ecotype is believed to have been formed by adaptation through the natural distribution or through the artificial cropping practice.

\section{Literature cited}

ARIGA, T. 1943. Agr. \& Hort. 18. 669, Tokyo BUREAU of Agriculture, Department of Agriculture and Commerce. 1919. Bul. Agr. 74. 272

KoBAYASHI, M. 1946. The soybean, ZakkokuShoreikai, Tokyo

Matsuo, T. 1952. Bul. Nat. Inst. Agr. Sci. D 3, Tokyo

NAGAI, I. 1943. Cultivation of crops II. 403 Yokendo, Tokyo

NAGATA, T. 1956. The soybean, 38 Tokyo
Van Overbeek, J. 1938. Bot. Gaz. 100. 133 1935. Proc. Nat. Acad. Sci. 21. 292 SAito, K. 1943. Agr. \& Hort. 18. 634, Tokyo SkooG, F. \& TSUI, C. 1951. Plant Growth Substances, Univ. Wisc. Press.

Thiman, K. V. \& Skoog, F. 1934. Proc. Roy. Soc. B 114

VAvilov, N. I. 1926. Appl. Bot. Plant Breed. 17 (2)

\section{小豆における種生態学的研究（草型による生態型の決定）}

\section{田崎順 郎 \\ (新潟大学教育学部)}

小豆结古い作物ではむるが地理的分布が狭く品種数も 此較的少ない。又在来種が土着していて自然分有の乱れ も少なく，生態型が見分けやすいので作物の種生態学的 研究によい材料であるを思わ礼る。ここでは草型により 生態型を決定し品種の分類を試みた。草型を草型構成要 素一一直立・分校性, 茎太さの变邀，茎基部の幅，最長 分枝長——以分析し，それらに階級值を与光相乗積を求 如草型を数量的に概镜した。草㤠の基本をなす分枝性火 上り類別すると第 1 群：直立性，第 2 群：分枝性中， 第 3 群：分枝性大，第 4 碓：分枝性最大となる。各群は 令象的に類似した地域に分布しているので，分布地域に
より生態型学分けると，第 1 群：A型，日本列島型，第 2 群: B型, 暖地夏型, 第 3 群: C 型, 大陸型, 第 4 群：D型, 暖地秋型となる。更に草型, 分布地域気像の 共通性から細分して A 1型：北海道型，A 2型：宋北・ 裹日本型, B 1型：日本西南暖地夏型, B 2 型：東海関東 夏又山中間型, $\mathrm{C}$ 1型：満州・北支・朝鮮型， C 2 型大陸 中・南部の秋型と推定, 同じく同地方に B 1 型類似の暖 地夏型原型を推定，D 1 型：日本西南暖地秋型，D 2 型： 山陽近幾秋型とした。草型の变異等により小豆品種の分 化，成立関し一応の種生態学的考察を加光た。 